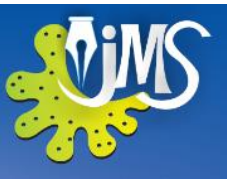

\title{
Status of Ground Water in Vavuniya City, Sri Lanka with Special Reference to Fluoride and Hardness
}

\author{
Swarna Piyasiri ${ }^{1,2}$ and Indunil Senanayake ${ }^{2}$ \\ ${ }^{1}$ Faculty of Graduate Studies, Kotelawala Defence University, Sri Lanka. \\ ${ }^{2}$ Faculty of Applied Sciences, University of Sri Jayewardenepura, Sri Lanka.
}

\begin{abstract}
Vavuniya $\left(8.75^{\circ}\right.$ North latitude, $80.5^{\circ}$ East longitude and 1 meters elevation above the sea level) is in the dry zone of Sri Lanka. The only stagnant water body of the Vavuniya city is the "Vavuniya Tank" which is located in the city center and it is highly polluted due to solid \& liquid wastes received from its catchment. Therefore the main source of water for drinking purposes in Vavuniya city is the groundwater. Due to lack of water, people even use the agro wells for their domestic purposes.
\end{abstract}

The main objective of this study is to analyze the quality of groundwater with particular reference to fluoride and hardness in the Vavuniya city and to demarcate the suitable groundwater resources using GIS maps. Therefore, this study is important for the Vavuniya city dwellers and water managers who seek water sources for distribution to the city.

As the study area of this research project, $10 \mathrm{~km}$ radius circle was selected from a middle point of the Vavuniya city. Then the circle area was divided into four zones namely A, B, C and D. Fifty wells, including dug wells and tube wells from each zone of the circle were sampled randomly. Sampling was undertaken during the intermediate season from March to April in 2011. Two hundred samples were collected during this period from the entire study area.

pH and conductivity were measured in each sample by using digital meters; $p H$ Meter model 340 WTW \& Conductivity Meter, 330 WTW. Fluoride was measured using HACH- D2700 spectrophotometer and Water Hardness was measured using stranded methods. Results were analyzed using MINITAB 14 and maps were prepared by using Arc GIS 10.1. For statistical analysis of data $R$ version 2.9.1 software package was used.

According to the results, north western part of the Vavuniya city (Zone A) indicated high concentration of fluoride and hardness and south eastern part of the Vavuniya city (Zone D) indicated low concentration of fluoride and hardness. Based on the other water quality data, it is recommended that the water from ground water in the south eastern part of the Vavuniya city is suitable for consumptive purposes. Nevertheless, the North Western part of the Vavuniya city could be considered as a sensitive area for groundwater unsuitable for consumption due to high fluoride and hardness Corresponding author: Swarna Piyasiri, Email: swarnapiyasiri@yahoo.com 
levels exceeding the recommended threshold values according to WHO water quality standards for drinking purposes.

KEYWORDS: Vavuniya City, groundwater, fluoride, hardness 


\section{INTRODUCTION}

Vavuniya $\left(8.75^{\circ}\right.$ North latitude, $80.5^{\circ}$ East longitude and 100 meters elevation above the mean sea level) is in the geological division of Western Vijayan complex, which consists of microcline biotite gneisses, hornblende gneisses, migmatites and granites formed under almandineamphibolitefacies (Dissanayake \& Weerasooriya 1985).

Fluoride is particularly available in rocks, soils, and in biological chains of living organisms. It has higher electronegativity and reactivity. It occurs naturally in water due to weathering of rock that contains fluoride rich minerals such as Hornblende, Biotite, Apatite and Fluorite. It can also leach into water from anthropogenic inputs such as fertilizer and farming activities which elevate fluoride levels in water (Jayawardana, et al, 2010).

Suitability of ground water for drinking purpose is one of the major problems in Dry Zone. Agro wells and dug wells in the study area of the Vavuniya city are constructed in the regolith above the hard rock which contributes to high fluoride levels in ground waters. The dry zone regolith aquifers are well known for high fluoride concentrations and fluoride-related endemic diseases and chronic renal failure with unknown etiology $(\mathrm{CKDu})$ is a common problem in such areas (Chandrajith, et al, 2006).

Vavuniya tank is the only surface water body in the study area which is heavily polluted as it receives city garbage and waste effluent discharges from the immediate catchment. Therefore, the main source of drinking water in the study area is mainly the dug wells and tube wells due to lack of adequate pipe borne water and suitable surface water resources.
Due to rapid development and increased population and urbanization in Vavuniya, the water requirement for agriculture, industry, and domestic purposes has become an urgent need. Though the agrowells are constructed for agricultural purposes, people in this area, use even such wells for domestic and drinking purposes (Amarasinghe, 2006).

The objective of the present research is to find out the status of groundwater quality of Vavuniya city area with special emphasis on fluoride and hardness concentrations in order to locate and recommend suitable drinking water resources for the city dwellers. Therefore, this study will be helpful for the Water Supply and Drainage Board to find out suitable groundwater sources for distribution.

\section{MATERIALS AND METHODS}

As the study area, a $10 \mathrm{~km}$ radius circle was selected from the center of the Vavuniya city as illustrated in Figure 1. The inner circle is a $5 \mathrm{~km}$ radius circle closer to the Vavuniya city center and the outer circle is a $10 \mathrm{~km}$ circle around the Vavuniya city center. These circles are divided in to four zones, namely "Zone A" to "Zone D".

Table 1 illustrates the Grama Nildhari divisions located within $5 \mathrm{~km}$ circle and 10 $\mathrm{km}$ circles of different zones that would helpful to describe the location wise status of suitable and unsuitable ground waters in the study area precisely.

Fifty wells from each zone were sampled randomly including both dug wells and tube wells. Altogether two hundred samples were analyzed during the research period. Sampling was undertaken during the first intermonsoon from March to April in 2011 and two hundred water samples were collected. 


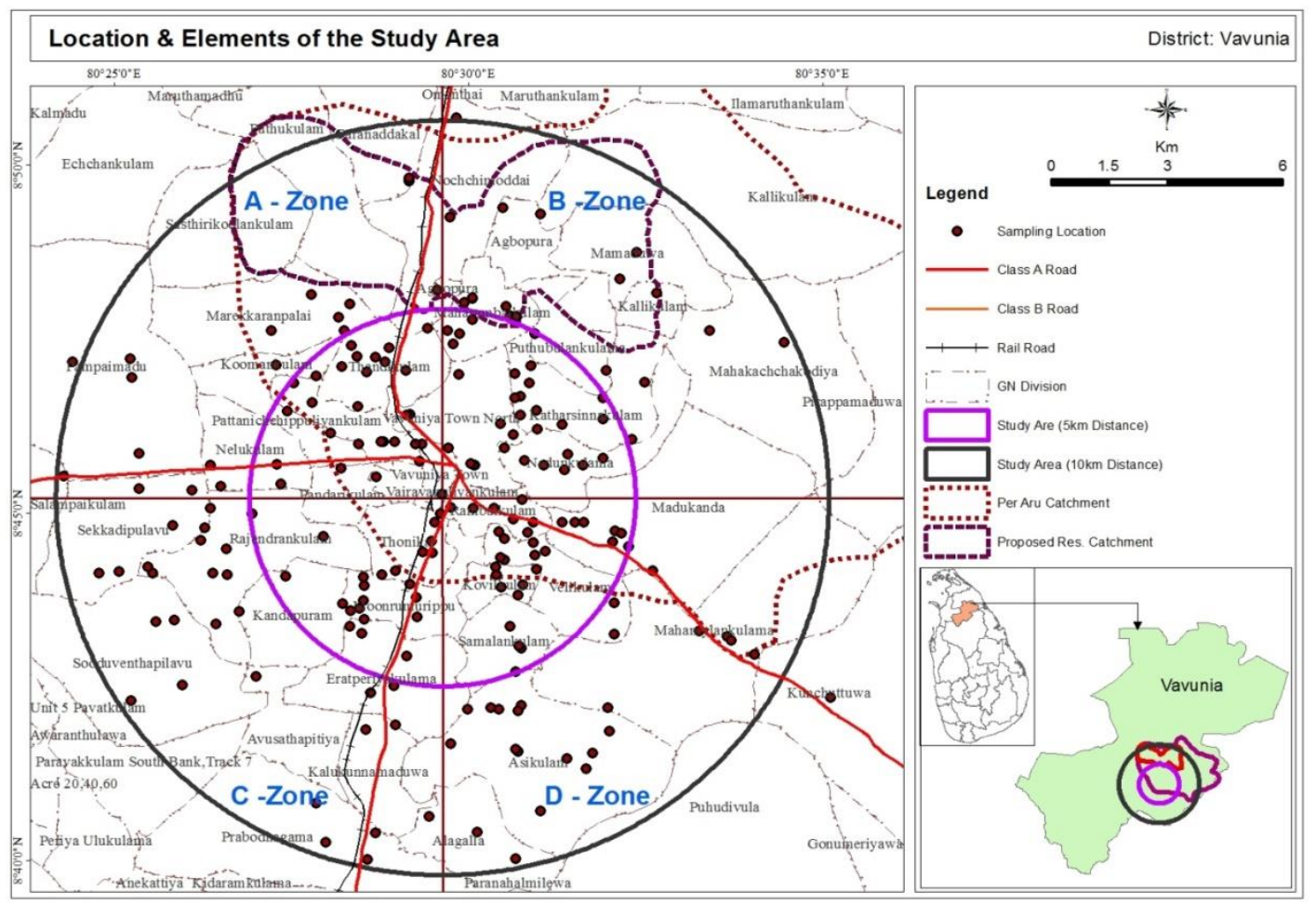

Figure 1. The selected $10 \mathrm{Km}$ radius study area with sampling locations in Vavuniya City

Table 1. GN Divisions located within different zones of the study area within $10 \mathrm{~km}$ circle \& $5 \mathrm{Km}$ circle from the Vavuniya town

\begin{tabular}{|c|c|c|c|}
\hline \multicolumn{4}{|c|}{ The GN Divisions located within $5 \mathrm{~km}$ circle in the 4 zones $(\mathrm{A}, \mathrm{B}, \mathrm{C}$ and D) } \\
\hline ZONE A & ZONE B & ZONE C & ZONE D \\
\hline Vairavpuliyankulam & $\begin{array}{l}\text { Vavuniya town North } \\
\text { (Pasrt) }\end{array}$ & Thonikal & Ranbaikulam \\
\hline Pandarikulam & Nedunkulama & Rajendrankulam (Part) & Kovikkulam \\
\hline Thandikulam & Katharsinnakulam & Kandapuram (part) & Samalankulam \\
\hline Vavuniya town North & Puththulankulama (part) & Moorumurippu & Vekkulan \\
\hline Nelukulam (part) & $\begin{array}{l}\text { Maharambankulam } \\
\text { (part) }\end{array}$ & Eratperiyakulama (Part) & \\
\hline \multicolumn{4}{|c|}{ The GN Divisions located within $10 \mathrm{~km}$ circle in the 4 zones $(A, B, C$ and D) } \\
\hline Sasthirikoeankulam & Nochchimoddai & Sekkadipulavu & Asikulam \\
\hline Puthukulam & Agbopura & Rajendrankulam (Part) & Alagalla \\
\hline Paranaddakulam & $\begin{array}{l}\text { Maharambankulam } \\
\text { (Part) }\end{array}$ & Kandapuram (part) & Mahamylankulam \\
\hline Marekkaranpalai & Kallikulam & Sooduventhapilavu & Madukanda \\
\hline Koomankulam & Mamaduwa & Kandapuram (part) & \\
\hline Pampaimada & Mahakachchakodiya & Avusathpitiya & \\
\hline Pattanichchippuliyankulam & Puthulankulama & Kalukunnamaduwa & \\
\hline Salampaikulam (part) & & Prabodhagama (Part) & \\
\hline Nelukulam (Part) & & $\begin{array}{l}\text { Paravakkulam south } \\
\text { bank Track } 7\end{array}$ & \\
\hline
\end{tabular}


In each groundwater sample collected from the wells, $\mathrm{pH}$ and conductivity were measured using $\mathrm{pH}$ meter (WTW model 340) and conductivity meter (WTW model 330) on the site. Rest of the samples was transported to the laboratory in temperature controlled cool boxes and analysis was done within 1- 2 days. Fluoride was measured using HACH- D2700 spectrophotometer and Hardness was measured using stranded methods (Silva et al, 1996).

Statistical analyses of the measured parameters were carried out using statistical package $\mathrm{R}$ version 2.9.1. Analyses of variance of the four areas with respect to tested water quality parameters were done using Pearson Product Moment Correlation Coefficient. Since normality assumption is violated, non-parametric Method: KruskalWallis One way analysis of variance test was used.

GIS Maps of the study area with different parameters were developed using Arc GIS 10.1 .

\section{RESULTS AND DISCUSSION}

\subsection{Summary of water quality parameters}

Table 2 illustrates the summary of the water quality parameter values of 200 wells observed during the investigation. According to Table 2 the highest conductivity and Hardness values were observed in the ground water resources of "A Zone" of the study area. Also highest Fluoride values also were recorded in "A Zone" of the study area indicating unsuitability of such waters for drinking purposes.
Table 2. Summary of the selected water quality parameters in the study area

\begin{tabular}{|c|c|c|c|c|c|c|c|c|}
\hline \multirow[b]{2}{*}{$\underset{Z}{\mathbb{Z}}$} & \multicolumn{2}{|c|}{$\begin{array}{c}\mathrm{EC} \\
(\mu \mathrm{s} / \mathrm{cm})\end{array}$} & \multicolumn{2}{|c|}{$\begin{array}{c}\text { Fluoride } \\
\text { (mg/L) }\end{array}$} & \multicolumn{2}{|c|}{$\begin{array}{c}\text { Hardness } \\
(\mathrm{mg} / \mathrm{L})\end{array}$} & \multicolumn{2}{|c|}{ pH } \\
\hline & $\Xi$ & $\stackrel{凶}{\tilde{E}}$ & $\Xi$ & $\stackrel{\text { E }}{\Sigma}$ & $\equiv$ & $\stackrel{\check{J}}{\Sigma}$ & $\Xi$ & $\stackrel{\check{E}}{\Sigma}$ \\
\hline A & 490 & 4480 & 0.36 & 3.03 & 160 & 1424 & 6.48 & 8.00 \\
\hline B & 360 & 1700 & 0.12 & 2.21 & 119 & 573 & 7.00 & 8.50 \\
\hline $\mathrm{C}$ & 290 & 1850 & 0.11 & 1.86 & 134 & 402 & 7.20 & 8.80 \\
\hline D & 230 & 1680 & 0.23 & 1.7 & 149 & 409 & 7.20 & 8.40 \\
\hline
\end{tabular}

\subsection{Spatial Distribution of Conductivity}

Figure 2 illustrates the distribution pattern of Conductivity in the study area. The highest conductivity values in the range of 2000 to 4000 is recorded in some areas within the "A zone" of the study area (indicated in dark blue colour).

These wells are located in the GN divisions of Pandarikulam, Paranaddakulam, Marekkaranpalai and northern part of Rajendrankulam (which is located at the margin of Zone C). Ground water resources located in such areas are highly unsuitable for drinking purposes as they exceed the threshold values for drinking purposes.

\subsection{Spatial distribution of Fluoride in the study area}

Figure 3 illustrates the spatial distribution of fluoride in Vavuniya city. The fluoride levels were high in "Zone A" and reach up to about 3.0 $\mathrm{mg} / \mathrm{l}$ in some locations (see Table $1 \&$ Figure 3) compared to the other zones. The dry zone regolith aquifers in this zone may contribute to the high fluoride concentrations. 


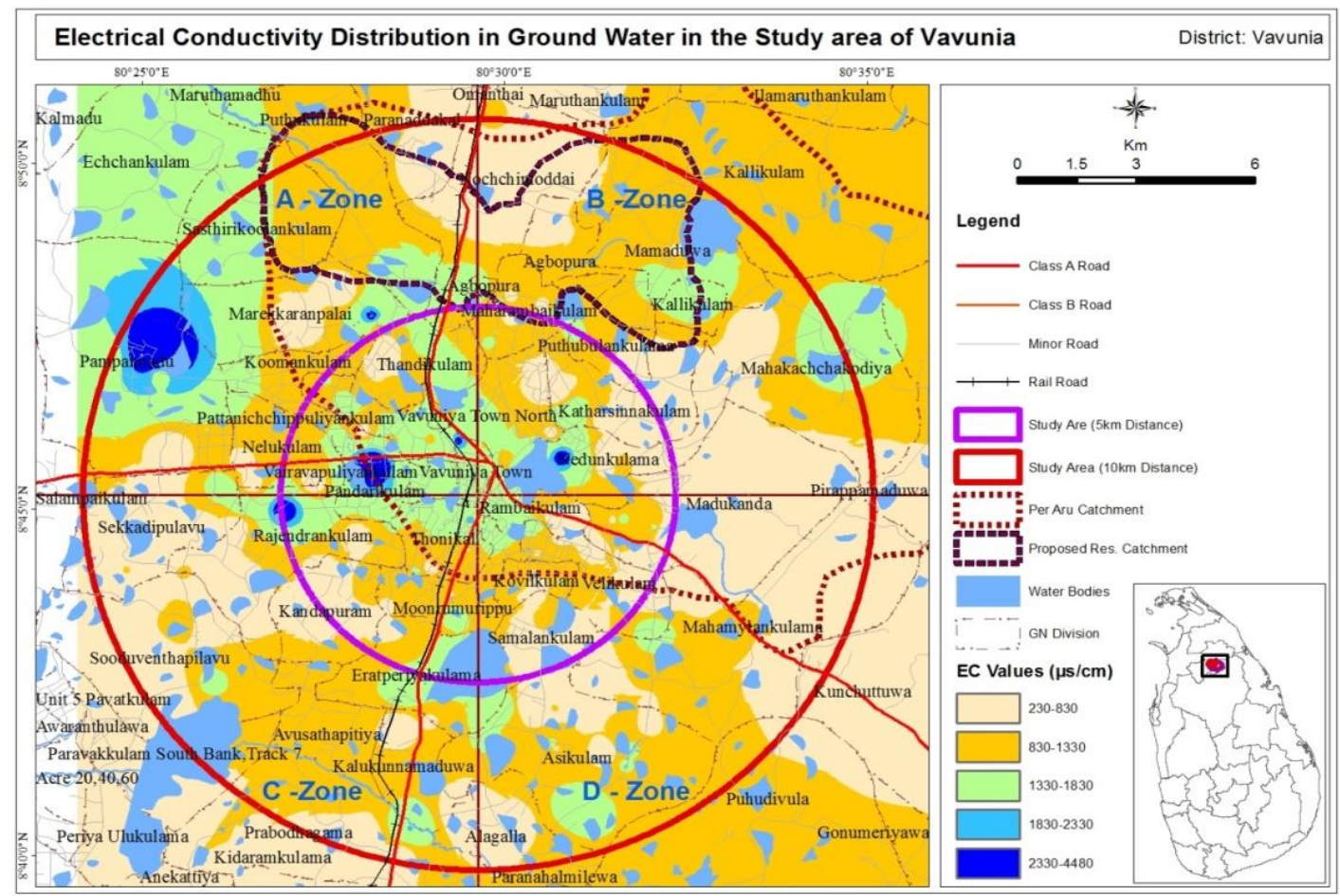

Figure 2.Distribution of Electrical Conductivity (EC) values in the study area (Source of base map- survey Department)

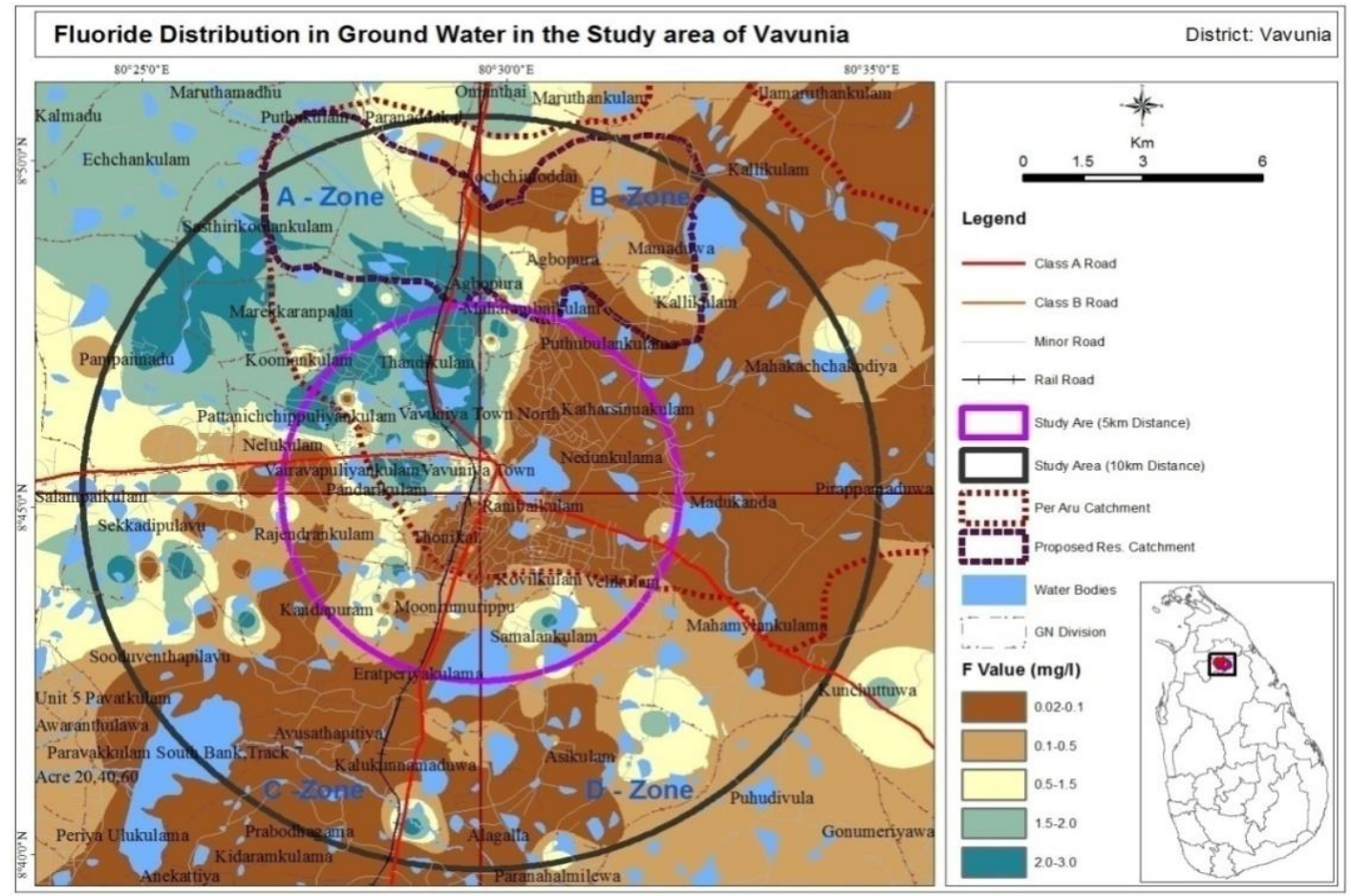

Figure 3.The spatial distribution of Fluoride in Vavuniya district 


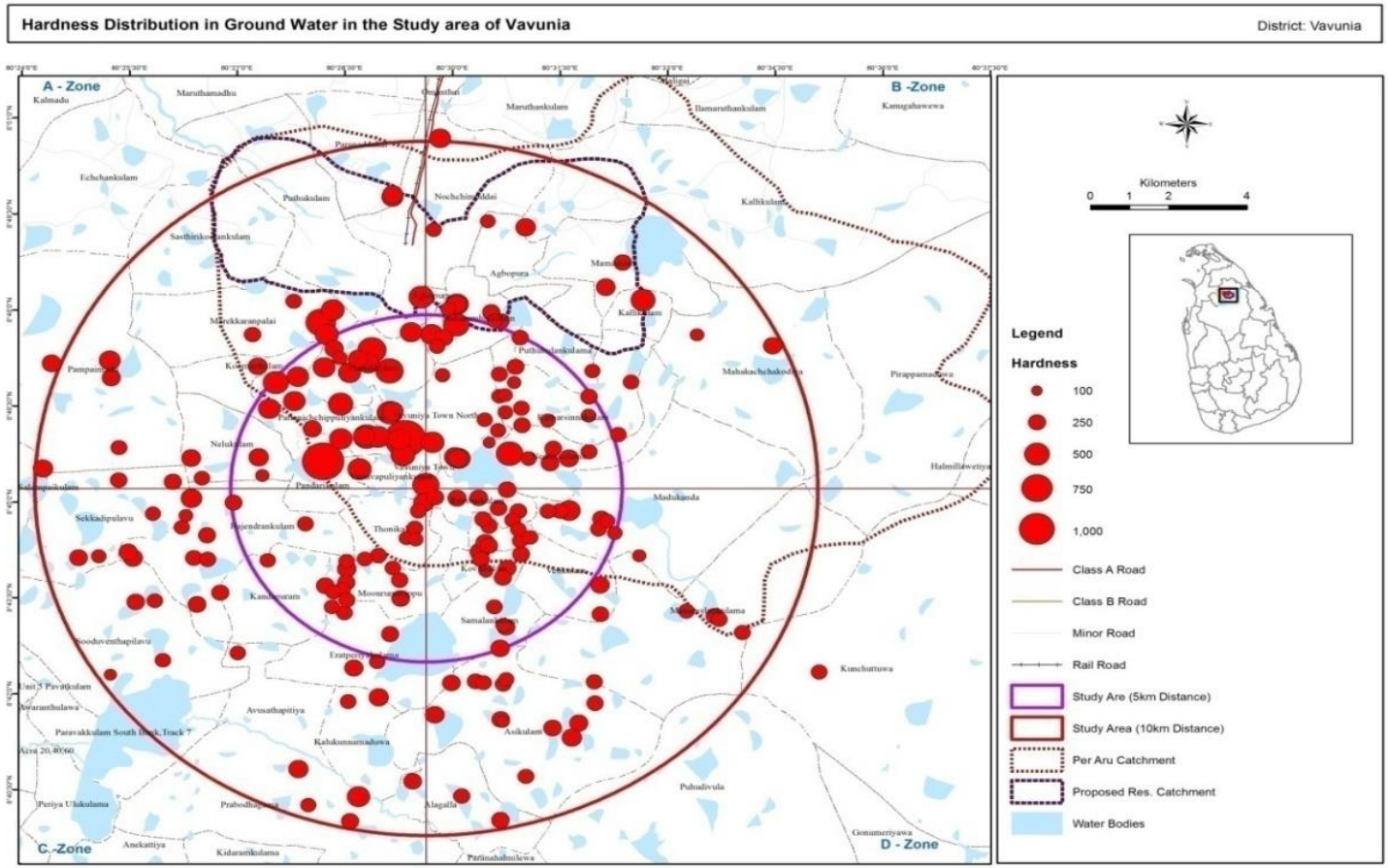

Figure 4.Hardness distribution in the study area

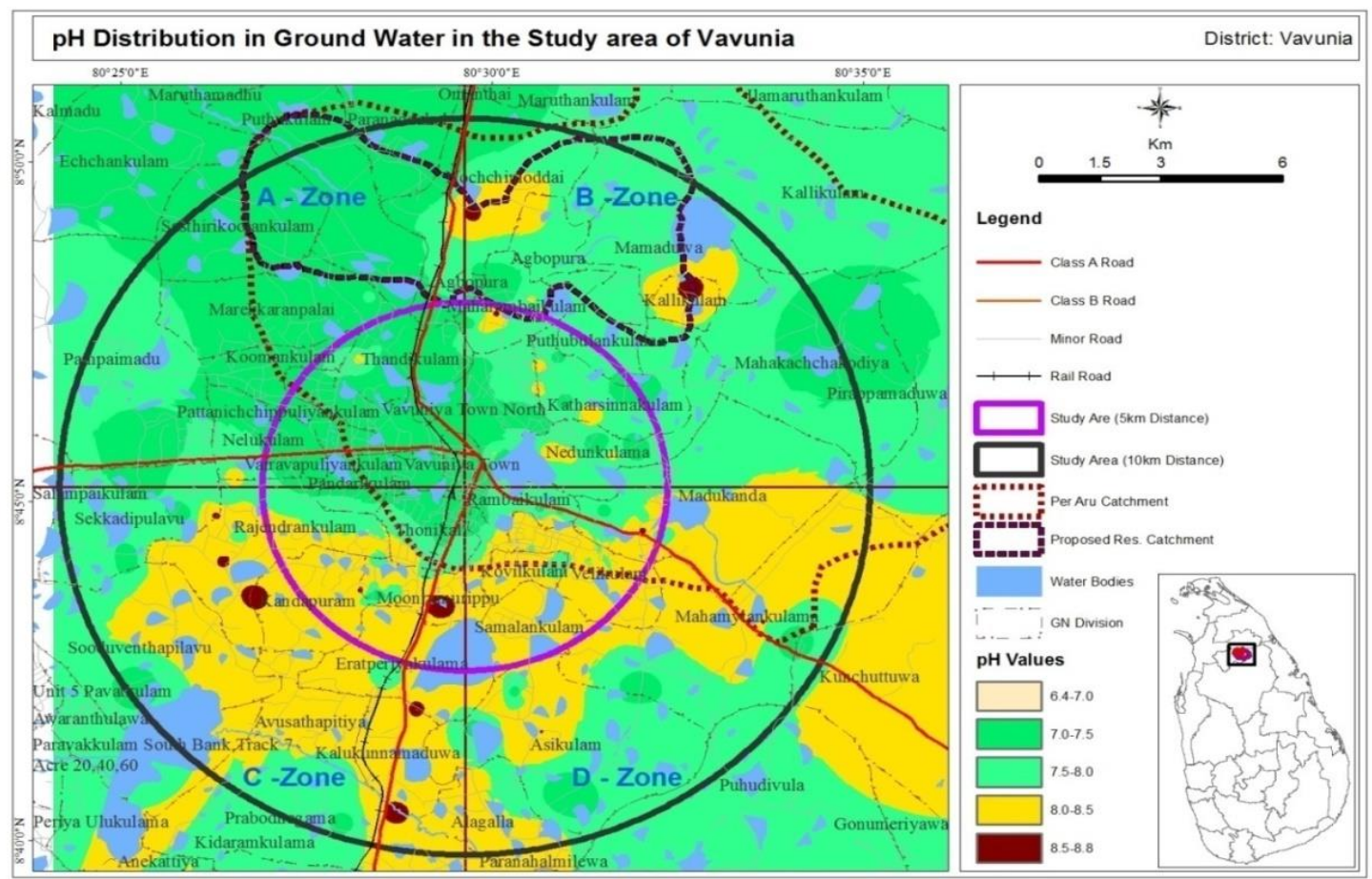

Figure 5.pH distribution in the study area 
According to Chandrajith et al (2012) the climate and hydrological conditions appear to play a major role in the geochemical distribution of fluoride in groundwater and according to their fluoride map of Sri Lanka, Vavuniya also belongs to $1-1.5 \mathrm{mg} / \mathrm{l}$ range of fluoride levels in ground waters. Over $2.0 \mathrm{mg} / \mathrm{l}$ fluoride in drinking water can cause renal damage in children, and the degree of damage increases with the increasing content of fluoride in drinking water (Chandrajith et al. 2011).Therefore, the wells located in "Zone A" of the study area cannot be recommended for consumptive purposes.

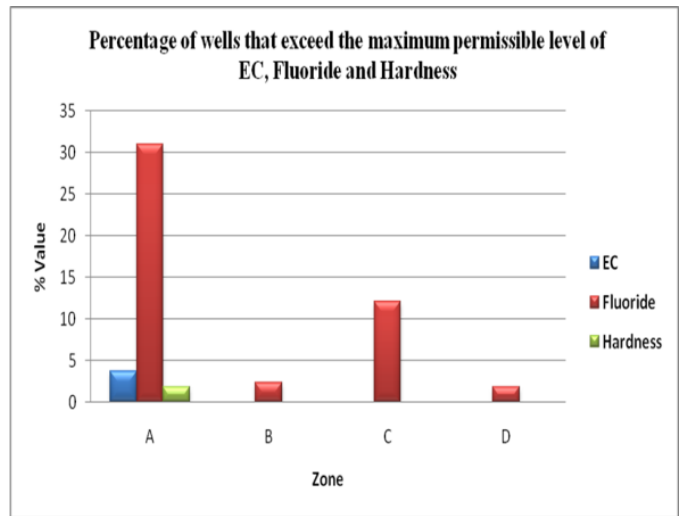

Figure 6.Percentage of wells that exceed, EC, Fluoride and Hardness in wells located within different zones of the study area

\subsection{Spatial distribution of Hardness}

Figure 4 illustrates the distribution of hardness in the study area. This also indicates high hardness values above threshold levels for human consumption according to WHO guidelines in the "Zone A" of the study area. The hardness values vary from 100 to $1000 \mathrm{mg} / \mathrm{L}$. The hardness values around $1000 \mathrm{mg} / \mathrm{L}$ were found mostly in the GN divisions located within the $5 \mathrm{~km}$ radius circle of "Zone A". The GN divisions affected are Vairavpuliyankulam,
Pandarikulam, Thandikulam, Vavuniya town north and part of the Nelukulam.

According to Chandrajith et al (2011), high $\mathrm{Ca}$ in the presence of $\mathrm{F}$, Calcium Fluoride $(\mathrm{CaFl} 2)$ is said to be formed, which is insoluble in water causing Kidney Tubular Damage. Therefore, the high hardness levels recorded from the Zone A of the Vavuniya city indicates its unsuitability for drinking purposes particularly due to presence of high Fluoride levels also in the same area.

According to Herath and Ratnayake (2010), one fourth of the wells in Anuradhapura, Polonnaruwa, Puttalam and Vavuniya contain Fluoride levels unsafe for human consumption. In addition to fluoride, total iron, total hardness and chloride contents also are high in these areas. In the "Zone A" of the study area of Vavuniya has high fluoride levels up to $3.0 \mathrm{mg} / \mathrm{l}$ and also in this zone, high hardness levels up to about $1000 \mathrm{mg} / \mathrm{l}$ occur in some wells indicating unsuitability for drinking purposes.

Apart from that some studies indicate potential health problems due to consumption of water with high hardness levels. Pallav (2013) indicates water hardness as a causative effect on cardiovascular mortality. The author further states that several epidemiological investigations have demonstrated the relation between risk for cardiovascular disease, growth retardation, reproductive failure, and other health problems and hardness of drinking water or its content of magnesium and calcium.

\section{5. $\mathrm{pH}$ distribution}

Figure 5 illustrates the $\mathrm{pH}$ distribution within the study area. In most wells $\mathrm{pH}$ levels were in the normal range of 6.4 to 7.5. However, in few wells high $\mathrm{pH}$ values of 8.5 to 8.8 were recorded. 


\subsection{The wells which exceed the WHO water quality standards for consumption}

Figure 6 illustrates the percentage of wells which exceed the water quality standards for conductivity, Fluoride and hardness in different zones of the study area.

The highest percentages of $3.64 \%$ of wells, (with high conductivity), $30.91 \%$ of wells with high Fluorides and $1.82 \%$ wells with high hardness values exceeding the maximum permissible levels were recorded in Zone A of the study area. As high percentages of wells exceeding permissible levels for Fluoride, Hardness and EC are recorded from "Zone A" of the study area, wells in "Zone A" of the study area are unsuitable for drinking purposes and could be considered as a sensitive area for unsuitable drinking waters.

In the other zones, wells exceeding the threshold levels for Fluoride are; around $12 \%$ in "Zone C" and around $2.5 \%$ in Zones B \& D. Conductivity values in the wells located within the other areas were less than the maximum permissible levels for drinking purposes.

According to Figure 6 most of the wells exceed the maximum permissible level of fluoride in Zone A of the study area. Exposure to natural fluorides in the environment and its nephrotoxic effects are not well known, many animal experiments reported that the kidney damage can occur even at lower levels of fluoride exposure over longer periods of time (Chandrajith et al, 2011). Therefore it is advisable not to use such well waters in Vavuniya city area for drinking purposes.

\subsection{Statistical analysis}

Correlation Analysis was done for each pair of variables for each zone using Pearson Product Moment Correlation
Coefficient using $\mathrm{R}$ version 2.9.1 software package. There are no significant correlations between variables except for Fluoride and EC in Area D. Therefore univariate analysis was done. Since Normality assumption is violated, Non parametric Kruskal-Wallis One way analysis of variance test was used. There were four findings of the analysis.

1. There are significant differences in Average EC in four sites $(\mathrm{P}=$ 0.04130).Multiple comparison test after Kruskal-Wallis average EC in A is significantly different from Average EC in D.

Table 3. Average EC in four sites. Multiple comparison test after Kruskal-Wallis

\begin{tabular}{|c|c|c|c|}
\hline Location & $\begin{array}{c}\text { obs.dif } \\
\text { Critical }\end{array}$ & $\begin{array}{c}\text { dif } \\
\text { difference }\end{array}$ & difference \\
\hline A-B & 18.635498 & 31.29100 & False \\
\hline A-C & 19.954545 & 29.83787 & False \\
\hline A-D & 31.518696 & 29.39220 & TRUE \\
\hline
\end{tabular}

2. There are significant differences in Average $\mathrm{pH}$ in four sites $(\mathrm{P}=0.00)$. Multiple comparison tests after KruskalWallis average $\mathrm{pH}$ in $\mathrm{A}$ is significantly different from Average $\mathrm{pH}$ in $\mathrm{B}, \mathrm{C}$, and $\mathrm{D}$.

Table4. Average $\mathrm{pH}$ in four sites. Multiple comparison test after Kruskal-Wallis

\begin{tabular}{|c|c|c|c|}
\hline Locations & $\begin{array}{c}\text { obs.dif } \\
\text { Critical }\end{array}$ & $\begin{array}{c}\text { dif } \\
\text { difference }\end{array}$ & difference \\
\hline A-B & 51.816667 & 31.29100 & TRUE \\
\hline A-C & 72.690000 & 29.83787 & TRUE \\
\hline A-D & 74.890566 & 29.39220 & TRUE \\
\hline
\end{tabular}

3. There are significant difference in Average fluoride in four sites $(\mathrm{P}=0.00)$. Multiple comparison tests after KruskalWallis average fluoride in A is significantly different from Average Fluoride in B, C, and D. 
Table5.Average fluoride in four sites Multiple comparison test after KruskalWallis

\begin{tabular}{|c|c|c|c|}
\hline Locations & $\begin{array}{c}\text { obs.dif } \\
\text { Critical }\end{array}$ & $\begin{array}{c}\text { dif } \\
\text { difference }\end{array}$ & difference \\
\hline A-B & 86.008442 & 31.29100 & TRUE \\
\hline A-C & 58.552727 & 29.83787 & TRUE \\
\hline A-D & 55.746312 & 29.39220 & TRUE \\
\hline
\end{tabular}

4. There are significant differences in Average hardness in four sites $(\mathrm{P}=0.00)$. Multiple comparison tests after KruskalWallis average hardness in $\mathrm{A}$ is significantly different from Average Hardness in B, C, and D.

Based on this analysis, there is significant difference with respect to Conductivity, Fluoride, Hardness \& $\mathrm{pH}$ values in "Zone A" of the study area compared to the rest.

"Zone A" is highly populated \& people use ground water in this area for consumption. Zones B \& C have moderate Fluoride \& conductivity values. "Zone D" has low fluoride and conductivity values \& suitable for consumptive purposes with additional water quality testing such as $\mathrm{E}$ coli etc. with required treatments for such parameters.

\section{CONCLUSION}

"Zone D" (south eastern part of the Vavuniya) is most suitable to extract ground water for consumptive purposes than the other three zones of the study area as the water quality remains below the threshold levels for drinking purposes. "Zone A" has high EC, Fluoride and Hardness values above the threshold levels recommended by WHO for drinking purposes compared to other three zones. Therefore most of the wells located in "Zone A" are not suitable for the drinking purpose and the GN divisions located in this zone are illustrated in Table1.

\section{ACKNOWLEDGEMENT}

The support given by Dr. Sarath Bannehaka, Department Statistics, University of Sri Jayewardenepura for statistical analysis of data and the facilities provided by dry zone water sector project is greatly appreciated.

\section{REFERENCES}

AMARASINGHE SR. Water quality and quantity assessment of agro wells in Vavuniya district for domestic and agricultural uses (in thesis), The Open University of Sri Lanka. 2006.

CHANDRAJITH R, PADMASIRI JP, DISSANAYAKE CB \& PREMATILAKA KM. Spatial distribution of fluoride in groundwater of Sri Lanka, J. Natn. Sci. Foundation Sri Lanka. 2012; 40(4):303309.

CHANDRAJITH R, NANAYAKKARA S, ITAI K, ATURALIYA TNC, DISSANAYAKE CB, ABEYSEKARA T, HARADA K, WATANABE $\mathrm{T} \&$ KOIZUMI A. Chronic kidney disease of uncertain etiology $(\mathrm{CKDu})$ in Sri Lanka: geographic distribution and environmental implications, Environmental Geochemical Health. 2011; 33: 267-278

CHANDRAJITH R, WIJEWARDANA G, DISSANAYAKE CB \& ABEYGUNASEKARA A. Biomineralogy of human urinary calculi (kidney stones) from some geographic regions of Sri Lanka. Environmental Geochemistry \& Health.2006; 28: 393-399.

DISSANAYAKE CB \& WEERASOORIYA SVR. The hydrogeochemical atlas of Sri Lanka, Publisher: Natural Resources, Energy \& Science Authority of Sri Lanka. 1985. ISBN 955-590-001-9.

HERATH G \& RATNAYAKE U. Ground water quality problems and issues in the 
dry-zone of Sri Lanka with special reference to fluoride contamination and Chronic Kidney Disease. 2010; 21-27, in South East Asian Water Environment 4, Edited by Kensuke Fukushi, Futoshi Kurisu, Kumiko Oguma, Hiroaki Furumai \& Psyche Fontanos, IWA Publisher, London. Available in www.iwapublishing.com. Accessed on $08^{\text {th }}$ Dec 2015.

JAYAWARDANA D T, PITAWALA HMTGA \& ISHIGA H. Groundwater Quality in Different Climatic Zones of Sri Lanka: Focus on the Occurrence of Fluoride. International Journal of Environmental Science and Development.2010; 1(3): 244250.

PALAV S. Potential Health Impacts of Hard Water. Int J Prev Med. 2013;4(8): 866-875.

SILVA EIL, NAMARATHNE SY, WEERASOORIYA SVR \& MANUWEERA L. Water Analysis-User Friendly Laboratory Field Manual, Sri Lanka. A J Prints, Dehiwala.1996 